not been told them. But, alas, the interests of a great business corporation seemed to demand the destruction of the last remnant of these most celebrated works of the glacial age. Many were the regrets expressed at the near prospect of the accomplishment of this real calamity to the interests of scientific education.

But so it was not to be. Mr. M. C. Younglove, the president of the company, then gave his word that the groove which had excited their admiration should be preserved. For three years the workmen have sacredly spared the spot. Gunpowder and dynamite have been kept from injuring these most wonderful exbibitions of nature's most wonderful geologic work, until we are permitted to record that to-day it has been placed beyond danger. At Mr. Younglove's invitation, Rev. Dr. Sprecher and myself have carefully surveyed the premises with him, and, on presentation of the case to the company at its annual meeting on the island today, the following resolution was unanimously passed:-

"Resolved, that, in the name of this corporation, the secretary and treasurer be and are hereby authorized to deed to Mr. M. C. Younglove a piece of the groove at the south-east corner of the north quarry at Kelley's Island, said deed to convey a strip of land fifty feet wide and one hundred feet long; said strip of land to be deeded by him to some scientific or historical society, to be preserved in perpetuity for the benefit of science."

This was adopted by unanimous vote of the stockholders.

The grooves thus preserved are probably the most remarkable in the world. They occur in the hard limestone of the vicinity, where the ice movement from the north-east encountered the projecting rock, and spent its main force upon it. As the ice pushed up and over the obstruction, a mingled mass cf mud, sand, gravel, and bowlders was shoved along beneath it. Under this force the bowlders became ploughshares; the gravel and sand, rasps and files; and the frozen mud, a pumice-stone to furrow and score and polish the whole. Originally a large area of this glaciated surface was exposed to sight. But in the progress of work upon the extensive quarry, the larger part of it has been removed. What is left, however, is ample for an object lesson. The portion of the groove preserved is thirty-three feet across, and the depth of the cut in the rock is seventeen feet below the line extending from rim to rim. Originally there was probably here a small depression formed by pre-glacial water erosion, into which the ice crowded the material which became its graving tool; and so the rasping and polishing went on in increasing degree, until this enormous furrow is the result. The groove, however, is by no means simple, but presents a series of corrugations merging into each other by beautiful curves. When exposed for a considerable time it will resemble nothing else so much as a collection of prostrate Corinthian columns, lying side by side on a concave surface.

These grooves have long attracted the attention of the collectors of geological curiosities. Those persons in Cleveland who are interested to see specimens of this remarkable phenomenon can gratify their desire by noticing the collection of stones on the Public Square, just opposite the First Presbyterian Church. This was placed there by the Western Reserve Historical Society, and contains one of the first millstones used in the country. But beside it is a notable fragment of one of the glacial grooves from Kelley's Island. Mr. Younglove also has a still more remarkable specimen in front of his residence at 614 Euclid Avenue. Specimens of these grooves have also been procured for the Harvard College Museum, and a specially large and fine one' was sent a year ago by Mr. Younglove to Oberlin, and adorns the college park in front of the library.

Col. Whittlesey paid much attention to the study of the grooves on Kelley's Island as they were in progress of being uncovered, and secured many fine specimens for the collection of the Historical Society, which can be seen in their rooms. The society also has a large number of original drawings of the grooves, executed by Col. Whittlesey, and accompanied by much unpublished descriptive matter. Neither has attention to those remarkable exhibitions of glacial action been confined to this country. In my recent work on the "Ice Age in North America," I have taken pains to introduce several photographs from this place. In a recent issue the London Athenoeum (March 28, 1891) fairly went into ecstacies over them, exclaiming, "How paltry appear the furrows ploughed by ice on our glaciated rocks beside the monstrous groovings eroded on the Sandusky Islands in the western part of Lake Erie, and figured from photographs, at pp. 233-242 of this book."

The direction of these grooves is a little south of west, corresponding to that of the axis of the lake. This is nearly at right angles to the course of the ice scratches on the summit of the water-shed south of this, between the lake and the Ohio River. The reason for this change of direction can readily be seen by a little attention to the physical geography. The high lands to the south of the lake rise about seven hundred feet above it. When the ice period was at its climax, and overran these high lands, it took its natural course at right angles to the terminal moraine, and flowed south-east, according to the direction indicated by the scratches on the summit. But when the supply of ice was not sufficient to overrun the high lands, the obstruction in front turned the course, and the resultant was a motion towards Toledo and the Maumee Valley, where, in the vicinity of Fort Wayne, an extensive terminal moraine was formed. The grooves on the islands near Sandusky were produced during that stage in the recession of the great ice-sheet.

The groove preserved is only a small portion of what still exists, but it would be too much to ask to have more given by the company. . As it is, the public spirit shown by the directors, gathered from Boston to Duluth, has rarely been equalled by a similar corporation. Quarrying has already proceeded nearly all around this specimen, and soon the monument preserved will be a monument indeed, the groove being left to cap a pedestal about thirty feet high, and conspicuous from every side. About one half the surface will be cleared of débris, so as to show fifty feet of the length of the groove, while the other half will remain as it is, beneath its protective covering of pebbles, gravel, sand, and mud, which acted as the graving tools in the firm grasp of the ice. In this condition it is to be presented to the Western Reserve Historical Society of Cleveland, to remain for the admiration and instruction of all future generations. I trust the citizens of the vicinity will appreciate the noble gift enough to occasionally visit the place and receive the deep impressions it is so well calculated to make.

Kelley's Island, O., June 9.

G. FREDERICK WRIGHT.

\section{Pacific Air over the Rocky Mountains.}

IN last August I called attention in Science to the enormous mass of Pacific air which for three months had been passing eastward over the mountains: also to the fact that there had been but little precipitation during the summer until near the middle of August, when, for the first time, solar halos appeared, and were followed by violent electrical storms. From September to the middle of last January the atmospheric circulation was in general feeble, consisting largely of gentle winds from the north-west. Late in January the south-west currents began to flow again, at first feebly, but becoming more and more persistent and aggressive. A remarkable series of storms bas followed, one storm following another at intervals of four days to three weeks. At first, after a rush of north wind had ended a storm, it would be one or two weeks before the south-west winds were re-established. But as time went on it took less and less time, until in April two of the worst of northers cleared off with the upper south-west wind still in possession of the field, rushing over the higher mountains as if nothing had happened, and in a few hours it became the surface wind on the plains. At present the plains near the mountains are wetter than for years.

I have had opportunity to observe these storms at a point 20 miles east of the mountains, 27 miles north-east of Colorado Springs, at 6,800 feet elevation, and near the top of the high ridge which extends east from the mountains known as the Divide between Arkansas and Platte waters. Seen from that place the most common development of the general storms was as follows. First, high cirrus streamers and films are seen coming from the quadrant south to west, more often from about south-west. For a day or more the surface winds continue variable, but finally the south-west wind descends to the surface. Then for several days the south-west wind continues, sometimes with a high velocity. 
The temperature rises, and the region no doubt by degrees becomes warmer than the adjacent regions or the high air above it.

Presently the time comes when the high cirrus rapidly thickens, the cigar-shaped masses of cirro-stratus or cirro-cumulus appear at lower levels, and soon a tumultuous mass of cumulo-stratus clouds develops far below. The latter frequently envelop the top of Pike's Peak, so they are from a mile to a mile and a half above the plains. These clouds soon coalesce into a continuous sheet, which develops fringes and festoons on its bottom and outer margin, and thus continues to descend. At this time there is usually but little surface wind. Sometimes the storm reaches this stage and then clears up again. When the cloud has nearly reached, the plains there is a sudden rush of wind at the surface, bearing snow or rain. Usually the storm is inaugurated by a succession of squalls or hail-storms, - sometimes from the north. These squalls are often electrical. As squall follows squall the festooned outer border of the storm cloud can be seen to enlarge laterally and sink to lower levels. The surface temperature rapidly falls, and the local storm-areas become connected by a great but not wholly homogeneous cloud of precipitation, which rushes either south or north over the Arkansas-Platte Divide. When the lower wind is at first from the south, it usually swings around to the east, then north-east, and finally north. This usually completes the storm, but not seldom the cycle is repeated. Often a rush of north wind for several hours is followed by a south wind, and then by a north wind again. During all this time there is more or less precipitation. Usually we are enveloped in the clouds of precipitation, but of ten there are small rifts in these clouds, through which the upper air movements can be observed. In this manner I have observed in almost every storm the higher clouds (mostly cirroid) coming rapidly from the south-west for one or two days after the under-rush of cold saturated air began transverse to their direction. No matter whether the under-currents are going north, south, or west, the storms usually continue till the upper cirrus comes from the north; then the surface wind soon turns into the north, and the storm clears off cold. The lower cloud from which the precipitation occurs is seldom homogeneous in structure. In almost all cases it consists of a series of squalls, the local stormareas being connected by stratus. This seems to be the general law of the Great Basin also. After general storms I have seen, both on' the Wasatch and Rocky Mountains, great variations in the depth of snow on plains and mesas that could not be accounted for by differences of topography and altitude. In a recent rainstorm that covered a large part of Colorado east of the mountains these local storms were unusually well differentiated. The general storm began as a series of small thunder-storms, affording both hail and rain, each electrical area showing massive black cumulus clouds, which could easily be distinguished from the leaden and rather homogeneous stratus which extended from one of the local storm-areas to another. At one time three of these local storms could be seen in different directions. The development of the storm was signalized by a great fall in temperature. All the clouds afforded rain, but the fall was much more rapid from the electrical areas.

On June 9 a storm occurred as follows. The upper cirrus had been coming from the south-west for about three days, and hot winds from the same quarter had prevailed much of the time at the surface. During the night of June 8-9 there had been a heavy dew, a rare occurrence on the plains. Early June 9 a series of broad tracts of cirro-stratus formed along the eastern base of the mountains. Their western edges were situated a little east of the mountains. So near as the eye could estimate, these clouds occupied the same position all day. The separate flocks and fibres could be seen moving rather rapidly from the south-west. Evidently new cloud-fibres were being formed at the western edges of the cloud masses as fast as those already formed moved northeastward.

During the afternoon there were numerous abortive attempts at storms on the mountains. Just before sunset an electrical storm began near the top of the Arkansas-Platte Divide. It was narrow, perhaps five or ten miles wide, from east to west, but it rapidly prolonged itself to a length of a hundred miles or more from north to south. The most important facts about this storm are these: the south to south-west winds which had prevailed at the surface during the day gave place to a violent cold wind from the north at the moment the storm-cloud was formed; moreover, this long, narrow storm was generated, as nearly as the eye could estimate, along the exact north-and-south line where during the earlier part of the day the formation of cloud had been going on along the western edges of the cirro-stratus tracts. The north wind raged at a high velocity for several hours.

This was peculiarly a plains storm. To the west there appeared but few clouds, and no storm of consequence was visible for at least two hundred miles along the mountains. Even Pike's Peak, who insists on dipping his head into every storm that comes into this region, had for once to be content with a few scattering clouds about his shoulders, and looked on in utter helplessness.

Summary. - (1) Over the mountain region there has been since January a very great and persistent movement of air from the south-west. (2) Unlike last summer, onls a few days have at any time elapsed before halos and sun-dogs have appeared near the sun. They have invariably been followed by a rush of cold at the surface, causing abundant precipitation. (3) During the general storms of the,winter and spring, the movement from the southwest continues one to three days after the lower clouds of precipitation have been formed in currents which travel hundreds of miles back and forth in directions transverse or even opposite to the upper movement. (4) The movement of clouds in the high atmosphere from the south-west is in most cases interrupted toward the end of a storm by high currents from the north or north-west; but in a few cases the movement from the south-west was either not interrupted or almost immediately resumed. (5) The formation of the clouds of precipitation during the general storms of winter and early spring proceeds from above downwards, and is usually aided by the development of local storms. There is a sudden and often great fall of temperature at the time the surface clouds of precipitation are formed, and this, too, whether the surface clouds go north or south. The general situation, then, is this : before the breaking of the storm the lower mile or two of the atmosphere consists of air from the south-west of a relatively warm temperature, and generally containing considerable moisture. The temperature is above the saturation point. When the storm breaks upon us the temperature suddenly falls below the point of precipitation and there is a great rush of cold air horizontally.

Several facts deserve special notice in this connection. First, the precipitation continues from five to forty or more miles after the surface under-current which contains the cloud of precipitation has passed the top of the Divide, hence while the air is being warmed by condensation while descending from five hundred to two thousand feet. Here is greater cooling than could take place from rarefaction alone while the air was being forced to higher elevations. Second, the cold under-current affords abundant precipitation, often for twenty-four to forty-eight hours,-long enough for three hundred to twelve hundred miles of wind to pass. It is therefore a moist wind.

Now, no cold wind from either north or south could become colder in sinking from higher to lower levels, nor could it. in descending to the earth become super-saturated with moisture, whereas it contained no clouds of precipitation at higher levels. We have therefore to look for the precipitated moisture in the lower atmosphere, which in this case is relatively warm up to the breaking of the storm. The most probable interpretation of the facts would seem to be this: the cool under-currents which bring the rain or snow consist mainly of the surface air, much of which is fresh from the Pacific region. This surface air becomes mixed with considerable bodies of cold air, which descend from above both at the fringed clouds and especially at the local storms. This cold air would be dry, but would receive radiation from the surrounding masses of warmer air, and thus cool them, and would partly mix with them. This cooling goes on in spite of the latent heat set free at the condensation of the vapor.

It is not my present purpose to discuss the mechanism of these movements whereby vast bodies of air leave an ocean warmed by the Japan current and press eastward so persistently over a dry, cold, and elevated plateau, and high range of mountains. That 
would involve the question of a great Pacific atmospheric whirl, comparable to the supposed general movement during winter about the area of low pressure in the northern Atlantic. It would also involve a comparison of our weather here when we are in the Atlantic whirl with that which comes when the Pacific circulation pushes eastward over the mountains. There are numerous other questions involved in these observations, but they are postponed.

Colorado Springs, Col., June 15.

G. H. STONE.

\section{Consecutive Lightning Flashes.}

AвоUт 5.45 P.M. yesterday, while travelling over the "Jersey flats" on the Delaware, Lackawanna, and Western Railroad, I saw toward the south-west no less than six strokes of lightning following the same path - a nearly vertical one - in quick succession. The number was obtained from the grouping or "phrasing," as it were, of the flashes, which impressed itself on my mind. First there was a single flash, then a group of three, and then a group of two. They followed one another so rapidly that their separate character could just be distinguished, and the duration of the six must have been less than a second. I was at first inclined to believe that the naths had been precisely the same, even to the slightest sinuosity, but I am now inclined to think that they varied slightly, and that this variation aided me in recognizing their separate character. I am not aware that so many consecutive strokes have ever been noticed before. It may be interesting to add that this morning's papers report great damage by lightning in Elizabeth, N.J., in the direction of the observed flashes.

ARThur E. Bostwick.

New York, June 17.

\section{Mocking-Birds and their Young.}

AN educated Southern lady made to me the following statement, which seems too extraordinary to be true. My informant honestly considers it a fact. Is it true, or is she deluded by some accident? I leave the matter for those learned in the lore of birds to decide.

My friend says that while living in Mississippi, she frequently took young mocking-birds from a nest near the house, and placed them in a cage hanging on the verandah. The parent birds came, not to feed the young, but to endeavor to liberate them, by plucking at the cage. Failing in this, my friend says that they invariably brought to their imprisoned young bitter-sweet berries, which poisoned them, the birdlings only living a very short time after receiving the berries. She further said that the captives would do well as long as the parent birds were kept from the cage, but if by any inadvertence the cage was left on the verandah while the family went into the house, on returning they would find the bitter-sweet, berries in the cage, and the little fledglings in a dying state. My informant further declared that this had occurred again and again within her experience, and that her grandfather gave strict orders that no mocking-birds should be captured, as their death would certainly be effected by the old birds. This is a strange story of bird-ways, that birds should be capable of choosing for their progeny death rather than captivity! I wish some of the Southern readers of Science would observe in the mocking-bird direction, and give us positive and recent information from careful experiment.

Fulton, Mo., June 16.

JULIA MCNAIR WRIGHT.

\section{Thunder-Storms.}

IT has been noticed in connection with thunder-storms in this vicinity this season that in every instance there has been an outflow of air in every direction from the storm, extending even beyond the area of precipitation and cloudiness. For example, in the case of a storm appearing upon the south-western horizon and moving due east, and passing then three or four miles south of this village, the weather-vane pointed directly toward it continuously, veering slowly from south-west to south-east, showing that the wind came steadily from the storm. The same thing also occurred in the case of a storm which appeared upon the north- western horizon and moved eastward, passing three or four miles north of the village. In this case the vane pointed directly toward the storm throughout, the winds being quite brisk. In other instances in which the storms passed directly over the village the same thing was manifest, the vane shifting sharply from west to east as the storms passed. In previous years I have noticed the puff of wind in front of an advancing thunder-storm moving in the same direction as the storm itself and occurring just before the rain begins to fall, but my attention has never been called to such an outflow of air in every direction as has been apparent in connection with thunder-storms recently. Whatever may be its explanstion, it certainly is entirely inconsistent with the idea of an indraught and uprush at the centre of the storms in which it occurs.

Lyons, N.Y., June 22. M. A. VEEDER.

\section{- BOOK-REVIEWS.}

The Modalist, or the Laws of Rational Conviction. By EDwARD John Hamilton. Boston, Ginn. $8^{\circ}$. \$1.40.

THE author of this work claims to have perfected the science of logic. He says in his introductory chapter: "The treatise now offered to the public is the result of long-continued studies which have had for their object to place the doctrines of logic on satisfactory foundations; and it would be false humility were the author to conceal his assurance that these studies have been successful. He claims to have completed a work which Aristotle left unfinished." And again he says, speaking of himself: "He knows what he has been enabled to do; he is certain that he has found the truth on every important point" (pp. 1 and 3).

When we come to examine the improvements that Mr. Hamilton claims to have made in the science, we find that they consist mainly in the introduction of modal syllogisms, that is, syllogisms in which the conclusion is expressed in terms of possibility, probability, or contingency, as distinguished from the ordinary, or pure, syllogism, in which the conclusion is categorical. Such syllogisms were treated of by Aristotle, but modern logicians have rejected them as not properly belonging to the science, since possibility, probability, etc., belong, not to the form of thought, but to its matter. They are properties, not of our thought, but of the facts and events that we think about, and therefore have no proper place in a work on theoretical logic. Mr. Hamilton, however, gives such modal syllogisms the foremost place among the forms of reasoning, affirming that "the pure syllogism is the secondary mode of thought, and should be interpreted by the modal." Yet he immediately adds that the pure syllogism " is the best expression of our ordinary reasonings" (p. 262), an admission which is fatal to his whole theory.

A nother of Mr. Hamilton's innovations consists in treating the principle of antecedent and consequent, which lies at the basis of the hypothetical syllogism, as the first principle of all reasoning, even in the ordinary syllogism. Such a turning of logic topsyturvy as Mr. Hamilton proposes seems to us the reverse of an improvement, and we believe it will be so regarded by thinkers generally.

\section{AMONG THE PUBLISHERS.}

AN illustrated article by Edwin Cंheckley, which introduces some of his new theories of physical culture, forms one of the features of the July Lippincott.

-Among its contents the Chautauquan for July has the following: "A Symposium - Where Should a College be Located?" by Julius H. Seelye, Henry Wade Rogers, James B. Angell, Hjalmar Hjorth Bovesen, W. R. Harper, and Herbert B. Adams; "Modern Methods of Treating Inebriety," by H. R. Chamberlain; "Objections to College Training for Girls," by Emily F. Wheeler; and "Elizabeth Thompson, the Philanthropist," by Frances E. Willard.

- The publishers of the Illustrated American of this city announce a Monthly Illustrated American. The monthly has been planned for over a year, and is offered to the public as "the cheapest and best illustrated magazine in the world." It is com- 